\title{
Immunocytochemical demonstration of cell wall components related to tissue compartments in the globoid galls induced by Clinodiplosis sp. (Cecidomyiidae) on Croton floribundus Spreng. (Euphorbiaceae)
}

\begin{tabular}{|r|l|}
\hline Journal: & Botany \\
\hline Manuscript ID & cjb-2017-0123.R2 \\
\hline Manuscript Type: & Article \\
\hline Date Submitted by the Author: & 18 -Oct-2017 \\
\hline $\begin{array}{r}\text { Complete List of Authors: } \\
\text { Is the invited manuscript for } \\
\text { consideration in a Special } \\
\text { Issue? : }\end{array}$ & $\begin{array}{l}\text { Teixeira, Cristiane; Universidade Federal de Minas Gerais } \\
\text { Oliveira, Denis; Universidade Federal de Uberlandia } \\
\text { Isaias, Rosy; Universidade Federal de Minas Gerais, Botânica }\end{array}$ \\
\hline Keyword: & $\begin{array}{l}\text { Cell wall carbohydrates, insect-plant interactions, monoclonal antibodies, } \\
\text { protein and pectin components, pectin-methylesterases }\end{array}$ \\
\hline \multicolumn{2}{|c}{} \\
\hline
\end{tabular}


Immunocytochemical demonstration of cell wall components related to tissue compartments in the globoid galls induced by Clinodiplosis sp. (Cecidomyiidae) on Croton floribundus Spreng. (Euphorbiaceae)

Cristiane Trindade Teixeira ${ }^{1}$, Denis Coelho de Oliveira ${ }^{2}$, Vinícius Coelho Kuster ${ }^{2}$ and Rosy Mary dos Santos Isaias ${ }^{1}$ *

1 Universidade Federal de Minas Gerais (UFMG), Instituto de Ciências Biológicas, Departamento de Botânica, Belo Horizonte, Minas Gerais, Brazil; ${ }^{2}$ Universidade Federal de Uberlândia (UFU), Instituto de Biologia (INBIO), Campus Umuarama, Uberlândia, Minas Gerais, Brazil.

* Corresponding author: rosy@icb.ufmg.br, phone: +55 31 3409-2687. 


\begin{abstract}
The dynamics of cell wall components during gall development are related to structural specialization to meet the defensive or nutritional requirements of gall tissues. Cell wall features have been studied mostly in galls induced by hemipterans (Psylloidea), while galls induced by Cecidomyiidae have been little explored. We applied monoclonal antibodies to epitopes of proteins and pectins in cell walls of non-galled leaves and galls induced by Clinodiplosis sp. (Diptera; Cecidomyiidae) on Croton floribundus (Euphorbiaceae). The complexity of tissue zonation in Clinodiplosis galls reflected the impairment of the activity of the pectin-methylesterases during development. The labeling of the epitopes of extensins in young galls denoted cell enlargement with resistant cell walls, while the labeling of the epitopes of AGPs, in senescent galls, indicated the involvement of these proteins with programmed cell death, at the end of cell cycles at the gall development site. We conclude that the cell wall profile in Clinodiplosis galls implies an imbalance between tissue porosity, cell-to-cell signaling, and resistance linked to tissue structural and functional compartments. Current data confirm the presence of the epitopes of extensins in young galls, and the compartmentalization of HGAs and RG-I in galls as an independent taxon feature.
\end{abstract}

Keywords: Cell wall carbohydrates, insect-plant interactions, monoclonal antibodies, protein and pectin components, pectin-methylesterases. 


\section{Introduction}

Studies on cell wall composition during the development of plant galls revealed a reorganization of cellulose microfibrils (Magalhães et al. 2014; Suzuki et al. 2015), protein, and pectin components (Formiga et al. 2013; Oliveira et al. 2014; Carneiro et al. 2015). Changes in the pectin composition of cell walls, especially in the degree of methyl esterification, may be related to the age of plant organs or to the functional profiles of cells and tissues (Dolan et al. 1997). Gall development requires manipulation of host-plant tissues and triggering of new morphogenetic patterns stimulated by the galling insect, culminating in the formation of tissue compartments at gall-development sites (Shorthouse et al. 2005; Oliveira et al. 2016; Bragança et al. 2017). The orchestration of cell growth, division and redifferentiation, as well as changes in plant cell wall composition are fundamental for the generation of new shapes (Majewaska-Sawka and Nothnagel 2000; Lev-Yadun 2003), which determines the gall morphotypes (Isaias et al. 2013, 2014).

Pectins are the main components of the primary cell walls in higher plants, and together with proteins influence functions such as porosity, adhesion, rigidity and flexibility, as well as regulating cell growth (Showalter 1993; Mohnen 2008; Albersheim et al. 2011). All evidence suggests that pectins are synthesized in the lumen of the Golgi apparatus by membrane-labeled, or associated, Golgi-localized glycosyltransferases that transfer glycosyl residues from nucleotide sugars to oligosaccharide or polysaccharide acceptors (Mohnen 2008). During the biosynthesis of pectins, some pectic glycosyl residues are removed by the action of pectin methylesterases (PMEs) and this demethylesterification results in new functions, such as an imbalance of rigidity and porosity in cell walls (Jolie et al. 2010; Albersheim et al. 2011). The use of immunocytochemical 
techniques to determine the degree of pectin methylesterification in cell walls can indirectly demonstrate the activity of PMEs (Liu et al. 2013), and consequently the dynamics of the cell wall structure during gall development (Oliveira et al. 2014; Carneiro et al. 2015). In addition to the pectin-associated functions, cell-to-cell adhesion and signaling are orchestrated by the arabinogalactan proteins (AGPs), a class of soluble, complex and highly glycosylated proteoglycans, and glycoproteins during plant morphogenesis (Fincher et al. 1983; Knox et al. 1991; Majewaska-Sawka and Northnagel 2000). Once the galling insect manipulates host-plant tissues to build the gall, are the functional roles and distribution of pectins and proteins in gall tissue components similar in all species of galling organisms?

Regarding tissue zonation, the galls induced by species of Psylloidea are relatively homogeneous, while galls induced by species of Cecidomyiidae have three specialized zones and are, therefore, among the most complex galls in nature. Accordingly, they can be useful systems to elucidate the different patterns of cell wall composition in tissue compartments throughout development. We examined the globoid leaf galls induced by Clinodiplosis sp. (Diptera: Cecidomyiidae) on Croton floribundus (Euphorbiaceae) (here termed Clinodiplosis galls), to document alterations in cell wall composition during the establishment of tissue zonation. We focused on three developmental stages of these galls and addressed the following questions: 1) what are the diagnostic anatomical features of Clinodiplosis galls? 2) which portions of Clinodiplosis galls have the greatest diversity and variation in terms of cell wall composition? and 3) what are the similarities between galls induced by Clinodiplosis and by species of Psylloidea? 


\section{Material and Methods}

Study area and sampling

Samples of Clinodiplosis galls $(n \geq 5)$ and mature leaves $(n \geq 5)$ of Croton floribundus were obtained from a population at Serra de São José $\left(21^{\circ} 00^{\prime}-21^{\circ} 02^{\prime} \mathrm{S}\right.$ and $044^{\circ} 00^{\prime}-044^{\circ} 15^{\prime}$ W), Tiradentes municipality, Minas Gerais state, Brazil. Samples of nongalled leaves, as well as young, mature, and senescent galls were fixed in $0.1 \mathrm{M}$ Karnovsky's solution in phosphate buffer ( $\mathrm{pH}$ 7.2) (Karnovsky 1965), and stored in 70\% ethanol (Johansen 1940).

\section{Anatomy and immunocytochemistry}

Leaf epidermal fragments $\left(1 \mathrm{~cm}^{2}\right)$ from the middle portion of the intercostal region were cleared in 10\% sodium hypochlorite (Kraus and Arduin 1997), washed in water, stained in 1\% safranin (Johansen 1940), and mounted in Kaiser's glycerin jelly (Kraus and Arduin 1997). Leaf samples (intercostal region and midrib) and galls (young, mature, and senescent stages) were embedded in 2-hydroxyethylmethacrylate (Historesin, Leica Instruments, Germany), sectioned at a thickness of $5 \mu \mathrm{m}$ with a rotary microtome (Leica ${ }^{\circledR}$ Jung Biocut, USA), stained with 0.05\% toluidine blue ( $\mathrm{pH} 4.0$ ) (O’Brien et al. 1964), and mounted in water.

For immunocytochemical analysis of cell wall composition, samples fixed in Karnovsky's solution and embedded in 2-hydroxyethylmethacrylate were sectioned at a thickness of $5 \mu \mathrm{m}$, followed by immersion in blocking solution [ $3 \%$ powdered milk in PBS $(\mathrm{w} / \mathrm{v})$ ] for $30 \mathrm{~min}$ to prevent cross-labeling. Afterward, the samples were incubated with primary antibodies (Table 1$)$ in PBS $(1: 10, \mathrm{v} / \mathrm{v})$, for $2 \mathrm{~h}$ at room temperature. Then, the 
samples were washed in PBS, incubated with goat anti-rat FITC-conjugated secondary antibody (Sigma ${ }^{\circledR}$, USA) in PBS (1:100 dilution) for 1-2 h, and mounted in 50\% glycerin. Digital images were obtained using a Olympus DP70 camera coupled to an Olympus BX51 fluorescence microscope, using an FITC filter, and the DP Manager version 2.1.1.163 and DP Controller version 2.1.1.183 from Olympus Corporation. All steps took place in the absence of light, and the experiments were replicated three times. For the control tests, the primary antibodies were omitted. All immunocytochemical data were submitted to image analysis in ImageJ (http://rsb.info.nih.gov/ij) and the intensity of fluorescence of the epitopes of pectins and proteins was evaluated by the intensity profile, as grayscale methodology (ImageJ, National Institutes of Health, USA). Triplicates were performed for each tissue of non-galled leaves and all stages of gall development. Three categories of intensity, weak ( $\leq 30$ gray value), moderate (31-49 gray value), and intense ( $\geq 50$ gray value), were established based on the highest and lowest values.

\section{Results}

\section{Leaf and gall structural profiles}

The anticlinal cell walls of the epidermis of non-galled leaves are straight or slightly wavy on both leaf surfaces (Fig. 1A,B). On the adaxial surface, the epidermis is uniseriate, with acicular trichomes formed by a single apical cell surrounded by basal cells (Fig. 1C). On the abaxial surface, the epidermis is uniseriate, with lepidote-stellate and unicellular glandular trichomes and paracytic stomata (Fig. 1B,C). The mesophyll consists of 2 layers of palisade and 4-5 layers of spongy parenchyma. Idioblasts with calcium oxalate druses are interspersed with mesophyll cells, and vertical columnar sclereids reach 
the epidermis on both surfaces and connect to the trichomes (Fig. 1C). The cortical region of the midrib has subepidermal collenchyma; and the vascular system is bicollateral.

The galls are globoid, sessile and hairy, and may occur isolated or in groups (Fig. 2A). The oviposition site is on the abaxial leaf surface (Fig. 2B) or on young stems. The galls are green when young and brown when senescent. They contain one central larval chamber, hosting a single larva (Fig. 2A-D).

The epidermis of the gall is uniseriate with acicular (Fig. 2D) and glandular trichomes. The cortex of the young gall consists of homogeneous parenchyma (Fig. 2C) and idioblasts with druses. At maturity, the ostiole of the gall faces the abaxial surface and is closed by simple non-glandular and lignified trichomes. The outer cortical layers and the lignified epidermis (Fig. 2E) constitute a mechanical layer. The median cortical parenchyma is $8-9$ layers thick, with anticlinally elongated cells, and isodiametric cells at the top of the chamber (Fig. 2E), interspersed with vascular bundles. The inner cell layers are nutritive and surround the larval chamber. The outer cortex of the senescent galls remains lignified, the median cortex is parenchymatic (Fig. 2F), and nutritive cells are absent.

\section{Immunocytochemical profiles}

Extensins (LM1). The epitopes of extensins were labeled by LM1 in the outer periclinal cell walls of the epidermis and in the aciculate trichomes of the non-galled leaves (Fig. 3A). These epitopes were not detected in young or in mature galls (Fig. 3B,C); they were moderately labeled in the epidermal cell walls and trichomes (49 gray value), and intensely 
labeled, especially in cell junctions of the outer cortex (58.6 gray value) of senescent galls (Figs. 3D, 4A).

Arabinogalactan-proteins (AGPS) (LM2). The epitopes of AGPs were not labeled by LM2 in any cell layer of non-galled leaves, or in young or mature galls (Fig. 3A,B,C). In senescent galls, the AGPs were weakly labeled in the cell junctions and middle lamella of the outer cortical cells (28 gray value) (Figs. 3D, 4B).

$\beta$-D-galactans (LM5). The epitopes of $\beta$-D-galactans were weakly labeled by LM5 in the cell walls of the lepidote-stellate trichomes of the non-galled leaves (25 gray value) (Fig. 3A). LM5 intensely labeled the epitopes of $\beta$-D-galactans in cell junctions of the cortex (61 gray value), in the outer periclinal walls of the cells around the larval chamber, and in the phloem parenchyma cells of the young galls (Figs. 3B, 4C,D). In mature galls, the epitopes of $\beta$-D-galactans were detected in the median and inner cortical cells (Fig. 3C), labeled with moderate intensity mainly in cell junctions of the median cortical parenchyma, and in the inner cortical cells. In senescent galls, the epitopes of $\beta$-D-galactans were more intensely labeled by LM5 in the lignified cell walls of the outer cortex ( 57 gray value) and moderately labeled in the trichomes (49 gray value) (Figs. 3D, 4E).

$\alpha$-L-arabinans (LM6). The epitopes for $\alpha$-L-arabinans were weakly labeled by LM6 in the epidermal cell walls (20 gray value) of non-galled leaves, and moderately labeled on the walls of spongy parenchyma cells (44 gray value) (Fig. 3A). In young galls, these epitopes were labeled moderately in the cell walls of the trichomes around the ostiole (49 gray 
value) (Fig. 4F). In mature galls, the epitopes of $\alpha$-L-arabinans were labeled in the cell walls of the trichomes; the middle lamella of the lignified cells of the outer, median and inner cortices; and the walls of cells around the larval chamber (Figs. 3C, 5A). In senescent galls, the epitopes of $\beta$-D-galactans were intensely labeled by LM6 in the lignified cell walls of the outer cortex (60 gray value) and moderately labeled in trichomes (44 gray value) (Fig. 3D).

Partially (or referred as low) methylesterified HGA (up to 40\%) (JIM5). The epitopes of the partially methylesterified HGAs were weakly labeled by JIM5 in the cell walls of the phloem, and in the middle lamella and cell junctions of all tissues of non-galled leaves (Fig. 3A). These epitopes were labeled only in the cell walls of the trichomes of the young galls (Figs. 3B, 5B). The epitopes of the partially methylesterified HGAs were moderately labeled by JIM5 in the cell walls of the trichomes (49 gray value) and in the outer periclinal cell walls of the epidermis (49 gray value), and intensely labeled in the middle lamella of the outer cortical cell walls (62 gray value) of mature galls (Figs. 3C, 5C). In senescent galls, these epitopes were labeled in cell junctions of the outer cortex (Fig. 3D).

Highly methylesterified HGA (15-80\%) (JIM7). In non-galled leaves, the epitopes of the highly methylesterified HGAs were labeled weakly to moderately in the cell walls of the epidermis, the trichomes, the anticlinal cell walls of the palisade parenchyma, and the middle lamella and cell junctions of the phloem cells (Fig. 3A). In all the developmental stages of galls, the epitopes of the highly methylesterified HGAs were generally moderately labeled by JIM 7, but more intensely in the cell junctions (Figs. 3B-D, 5D-F). 


\section{Discussion}

Clinodiplosis galls develop a specialized tissue zonation related to the cecidogenetic field established by the galling stimuli. The three tissue zones or compartments of Clinodiplosis galls are similar to those reported for other cecidomyiid galls on Lantana camara L. (Verbenaceae) (Moura et al. 2008), Aspidosperma spruceanum (Oliveira et al. 2011), and Copaifera langsdorffii (Oliveira et al. 2010). The typical columnar sclereids crossing the non-galled leaf lamina of C. floribundus do not differentiate in the homogeneous parenchymatic cortex in young galls. Cell wall lignification is redirected to the epidermis and outer cortical cells of mature galls, a diagnostic feature of the outer tissue compartment of Clinodiplosis galls. Lignification of the outer cortex has been reported for Nothotrioza myrtoides galls on Psidium myrtoides (Carneito et al. 2014) and a cecidomyiid gall on Copaifera langsdorffii (Oliveira et al. 2010). This mechanical zone is believed to provide protection to the galling insect against natural enemies (Mani 1964; Stone and Schönrogge 2003). The parenchymatic feature of the median tissue compartment of Clinodiplosis galls provides water and carbohydrate storage, which is important for gall maintenance and movement of nutrients to the inner tissue compartment (Oliveira et al. 2010; Oliveira et al. 2014; Bragança et al. 2017). The inner cells surrounding the larval chamber constitute the innermost tissue compartment, the nutritive tissue, which is anatomically distinct from the adjacent median parenchyma. The nutritive cells are important for gall nutrition and as an energy-reserve site of gall cellular machinery (Bronner et al. 1992; Moura et al. 2008; Oliveira et al. 2010; Oliveira et al. 2016). The three tissue compartments of Clinodiplosis galls have different pectin and 
protein fractions in the cell walls, compared to the non-galled leaves. The alterations in cellwall composition result from the generation of new types of cells and tissues, as previously reported for three leaf-gall morphotypes on Baccharis reticularia (Formiga et al. 2013), for kidney-shaped galls on B. dracunculifolia (Oliveira et al. 2014), and for globoid galls on Psidium myrtoides (Carneiro et al. 2014).

\section{Pectin profiles during gall development}

The dynamics between $\beta$-D-galactans and $\alpha$-L-arabinans imply a functional shift of the cell wall (Jones et al. 1997) toward flexibility and/or adhesion (O'Donoghue and Sutherland 2012). In young psylloid-induced galls on leaves of Baccharis dracunculifolia, both $\beta$-D-galactans and $\alpha$-L-arabinans confer the flexibility necessary for the redefinition from the laminar organization to a folded margin of the gall (Oliveira et al. 2014). The epitopes of $\beta$-D-galactans are labeled by LM5 in the tissues of Clinodiplosis galls, especially in the young and mature stages. Accordingly, this epitope may be involved in processes of cell elongation, as demonstrated in the roots of Arabidopsis plantlets (McCartney et al. 2003). On the other hand, the epitopes of $\alpha$-L-arabinans labeled by LM6 were detected in Clinodiplosis galls at the mature and senescent stages. Similar results were obtained in Triozidae-induced galls on leaves of Psidium myrtoides (Carneiro et al. 2014). The epitopes of $\alpha$-L-arabinans are generally associated with cell adhesion, especially in the middle lamella, which implies a reduction in the capacity for cell expansion (Brummell et al. 2004). In Clinodiplosis galls, the epitopes of $\alpha$-L-arabinans detected at the mature and senescent stages indicate the end of growth and cell expansion, when the galls have reached their final size. 
The HGAs are synthesized in the highly methylesterified state, and are uniformly distributed in the cell walls (Ridley et al. 2001; Zhang and Staehelin 1992), as observed in Clinodiplosis galls. During gall development, de-methylesterification of the HGAs may occur, as reported for mature to senescent phases in galls on P. cattleianum (Carneiro et al. 2015). However, in three gall morphotypes induced on B. reticularia (Formiga et al. 2013), the kidney-shaped gall induced on B. dracunculifolia (Oliveira et al. 2014), and Clinodiplosis galls, synthesis of the HGAs appears to be continuous and the process of demethylesterification is impaired. This continues until senescence, when the HGAs are still labeled even in the walls of the mechanical outer cortical cells. The biotic stress induced by galling insects may occasionally block the activity of pectin methylesterases (PMEs), as observed in galls induced by Bacharopelma dracunculifolia (Psyllidae) on $B$. dracunculifolia (Oliveira et al. 2014). Maintenance of the methylesterified status has been associated with the conservation of juvenile features in some tissue compartments of Clinodiplosis galls.

The similarities in cell wall pectin composition between Clinodiplosis galls and galls induced by members of other taxa led us to assume that the cell wall dynamics seem to be taxon-independent.

Proteins: controversial functions in galls

The extensins, labeled with LM1, seem to reinforce plant cell walls (Sabba and Lulai 2005), which is also true for gall development sites. Formiga et al. (2013) related the extensins to the reinforcement of cell walls of mature pocket galls in B. reticularia, due to their large size and orientation of axis growth. Therefore, labeling of extensins with LM1 is 
expected in mature galls after cessation of growth, as proposed by Cassab (1998) for other plant organs, and is true for Clinodiplosis galls in the senescent phase. We infer that the presence of extensins recognized by LM1 in the outer layers of Clinodiplosis galls is the result of the mechanical pressure exerted during development, similarly to observations on nematode-induced galls on tobacco roots (Niebel et al. 1993). In contrast, the epitopes of extensins were labeled in the growth and development phase of globoid galls on $P$. myrtoides (Carneiro et al. 2014), when the cells at the site of gall development had not yet enlarged.

The labeling of the epitopes of arabinogalactan-proteins (AGPs) by LM2 in cell walls of senescent Clinodiplosis galls is another interesting aspect of our results. AGPs have been commonly related to the growth and differentiation of Arabidopsis roots (Ding and Zhu 1997). For some Neotropical galls, AGPs have been labeled by LM2 in either young or senescent galls (Formiga et al. 2013, Oliveira et al. 2014). Therefore, for Clinodiplosis galls in senescence, the AGPs may be related to programmed cell death because of the end of cell cycles at the gall development site.

\section{Main conclusions}

Clinodiplosis galls fit the proposed structural pattern for Cecidomyiidae-induced galls, and have some peculiarities regarding cell wall composition. The epidermis and outer cortex showed the greatest diversity and variation in terms of cell wall composition during the development of the gall. HGAs are maintained in both low and high levels of methylesterification during gall development, while the dynamics of RGI ( $\beta$-D-galactans and $\alpha$-L-arabinans) evolve from flexibility in young galls toward rigidity in mature and 
senescent galls. The rigidity of senescent galls is reinforced by the extensins, with signaling for programmed cell death by the AGPs. Currently, we conclude that this cellwall profile is related to the functionality of tissue compartments and is not related to the species of the gall inducer or the host plant.

\section{Acknowledgments}

The authors thank FAPEMIG, CAPES and CNPq for financial support, Dr. Valeria Cid Maia for the identification of the galling insect, and Ms. Janet Reid for the revision of English language.

\section{References}

Albersheim, P., Darvill, A.G., O’Neill, M.A., Schols, H.A., and Voragen, A.G.J. 2011. An hypothesis: the same six polysaccharides are components of the primary cell walls of all higher plants. In Pectins and pectinases. Edited by J. Visser and A.G.J. Voragen. Elsevier Sciences B.V., Amsterdam. pp. 47-53.

Bragança, G.F., Oliveira, D.C., and Isaias, R.M.S. 2017. Compartmentalization of metabolites and enzymatic mediation in nutritive cells of Cecidomyiidae galls on Piper arboreum Aubl. (Piperaceae). J. Plant Stud. 6: 11. doi:10.5539/jps.v6n1p11.

Bronner, R. 1992. The role of nutritive cells in the nutrition of cynipids and cecidomyiids. In Biology of insect-induced galls. Edited by J.D. Shorthouse and O. Rohfritsch. Oxford University, Oxford. pp. 118-140. 
Brummell, D.A., Cin, V.D., Crisosto, C.H., and Labavitch, J.M. 2004. Cell wall metabolism during maturation, ripening and senescence of peach fruit. J. Exp. Bot. 55: 2029-2039. doi:10.1093/jxb/erh227.

Carneiro, R.G.S., Pacheco, P., and Isaias, R.M.S. 2015. Could the extended phenotype extend to the cellular and subcellular levels in insect-induced galls? PLoS ONE, 10(6): e0129331. doi: 10.1371/journal.pone.0129331.

Carneiro, R.G.S., Oliveira, D.C., and Isaias, R.M.S. 2014. Developmental anatomy and immunocytochemistry reveal the neo-ontogenesis of the leaf tissues of Psidium myrtoides (Myrtaceae) towards the globoid galls of Nothotrioza myrtoides (Triozidae). Plant Cell Rep. 33: 2093-2106. doi:10.1007/s00299-014-1683-7.

Cassab, G.I. 1998. Plant cell wall proteins. Annu. Rev. Plant Physiol. Plant Mol. Biol. 49: 281-309. doi:10.1146/annurev.arplant.49.1.281.

Clausen, M.H., Ralet, M.C., Willats, W.G.T., McCartney, L., Marcus, S.E., Thibault, J.F., and Knox, J.P. 2004. A monoclonal antibody to feruloylated-(1 $\rightarrow 4)-b-D$-galactan. Planta, 219: 1036-1041. doi:10.1007/s00425-004-1309-3.

Derbyshire, P., McCann, M.M., and Roberts K. 2007. Restricted cell elongation in Arabidopsis hypocotyls is associated with a reduced average pectin esterification level. BMC Plant Biol. 7: 31. doi:10.1186/1471-2229-7-31.

Ding, L., and Zhu, J.K. 1997. A role for arabinogalactan-protein in root epidermal cell expansion. Planta, 203: 289-294. doi:10.1007/s004250050194.

Dolan, L., Linstead, P., and Roberts, K. 1997. Developmental regulation of pectic polysaccharides in the root meristem of Arabidopsis. J. Exp. Bot. 48: 713-720. doi:10.1093/jxb/48.3.713. 
Fincher, G.B., and Stone, B.A. 1983. Arabinogalactan-proteins: structure, biosynthesis, and function. Annu. Rev. Plant Physiol. 34: 47-70. doi:10.1146/annurev.pp.34.060183.000403.

Formiga, A.T., Oliveira, D.C., Ferreira, B.G., Magalhães, T.A., Castro, A.C., Fernandes, G.W., and Isaias, R.M.S. 2013. The role of pectic composition of cell walls in the determination of the new shape-functional design in galls of Baccharis reticularia (Asteraceae). Protoplasma, 250: 899-908. doi:10.1007/s00709-012-0473-8.

Isaias, R.M.S., Carneiro, R.G.S., Santos, J.C., and Oliveira, D.C. 2014. Gall morphotypes in the Neotropics and the need to standardize them. In Neotropical insect galls. Edited by G.W. Fernandes and J.C. Santos. Springer Netherlands, Dordrecht. pp. 51-67.

Isaias, R.M.S., Carneiro, R.G.S., Oliveira, D.C., and Santos, J.C. 2013. Illustrated and annotated checklist of Brazilian gall morphotypes. Neotrop. Entomol. 42: 230-239. doi:10.1007/s13744-013-0115-7.

Johansen, D.A. 1940. Plant microtechnique. McGraw-Hill, New York.

Jolie, R.P., Duvetter, T., Van Loey, A.M., and Hendrickx, M.E. 2010. Pectin methylesterase and its proteinaceous inhibitor: a review. Carbohydr. Res. 345: 2583-2595. doi:10.1016/j.carres.2010.10.002.

Jones, L., Seymour, G.B., and Knox, J.P. 1997. Localization of pectic galactans in tomato cell walls using a monoclonal antibody specific to $(1 \rightarrow 4)-\beta$-galactan. Plant Physiol. 113: 1405-1412. doi:10.1104/pp.113.4.1405.

Karnovsky, M.J. 1965. A formaldehyde-glutaraldehyde fixative of high osmolarity for use in electron microscopy. J. Cell Biol. 27: 137-138. 
Knox, J.P., Linstead, P.J., Peart, J., Cooper, C., and Roberts, K. 1991. Developmentally regulated epitopes of cell surface arabinogalactan proteins and their relation to root tissue pattern formation. Plant J. 1: 317-326. doi:10.1046/j.1365-313X.1991.t01-9-00999.x.

Knox, J.P., Linstead, P.J., King, J., Cooper, C., and Roberts, K. 1990. Pectin esterification is spatially regulated both within cell walls and between developing tissues of root apices. Planta, 181: 512-521. doi:10.1007/BF00193004.

Kraus, J.E., and Arduin, M. 1997. Manual básico de métodos de morfologia vegetal. EDUR, Seropédia.

Leroux, O., Leroux, F., Bagniewska-Zadworna, A., Knox, J.P., Claeys, M., Bals, S., and Viane, R.L.L. 2011. Ultrastructure and composition of cell wall appositions in the roots of Asplenium (Polypodiales). Micron, 42: 863-870. doi:10.1016/j.micron.2011.06.002.

Lev-Yadun, S. 2003. Stem cells in plants are differentiated too. Curr. Opin. Plant Biol. 4: 93-100.

Liu, Q., Talbot, M., and Llewellyn, D.J. 2013. Pectin methylesterase and Pectin remodelling differ in fibre walls of two Gossypium species with very different fibre properties. PLoS ONE, 8(6): e65131. doi:10.1371/journal.pone.0065131.

Majewaska-Sawka, A., and Nothnagel, E. 2000. The multiple roles of arabinogalactan proteins in plant development. Plant Physiol. 122: 3-9. doi:10.1104/pp.122.1.3.

Magalhães, T.A., Oliveira, D.C., Suzuki, A.Y.M., and Isaias, R.M.S. 2014. Patterns of cell elongation in the determination of the final shape in galls of Baccharopelma dracunculifoliae (Psyllidae) on Baccharis dracunculifolia DC. (Asteraceae). Protoplasma, 251: 747-753. doi:10.1007/s00709-013-0574-z.

Mani, M.S. 1964. Ecology of plant galls. Dr. W. Junk Publishers, The Hague. 
McCartney, L., Steele-King, C.G., Jordan, E., and Knox, P. 2003. Cell wall pectic (1-4)- $\beta$ D-galactan marks the acceleration of cell elongation in the Arabidopsis seedling root meristem. Plant J. 33: 447-454. doi:10.1046/j.1365-313X.2003.01640.x.

Mohnen, D. 2008. Pectin structure and biosynthesis. Curr. Opin. Plant Biol. 11: 266-277. doi:10.1016/j.pbi.2008.03.006.

Moura, M.Z.D., Soares, G.L.G.S., and Isaias, R.M.S. 2008. Species-specific changes in tissue morphogenesis induced by two arthropod leaf gallers in Lantana camara L. (Verbenaceae). Aust. J. Bot. 56: 153-160. doi:10.1071/BT07131.

Niebel, A., Engler, J.A., De Tiré, C., Engler, G., Van Montagu, M., and Gheysen, G. 1993. Induction patterns of an extensin gene in tobacco upon nematode infection. Plant Cell, 5: 1697-1710. doi:10.1105/tpc.5.12.1697.

O’Brian, T.P., Feder, N., and McCully, M.E. 1964. Polychromatic staining of plant cell walls by toluidine blue O. Protoplasma, 59: 368-373. doi:10.1007/BF01248568.

O’Donoghue, E.M., and Sutherland, P.W. 2012. Cell wall polysaccharide distribution in Sandersonia aurantiaca flowers using immune-detection. Protoplasma, 249: 843-849. doi:10.1007/s00709-011-0307-0.

Oliveira, D.C., Isaias, R.M.S., Fernandes, G.W., Ferreira, B.G., Carneiro, R.G.S., and Fuzaro, L. 2016. Manipulation of host plant cells and tissues by gall-inducing insects and adaptive strategies used by different feeding guilds. J. Insect Physiol. 84: 103-113. doi:10.1016/j.jinsphys.2015.11.012.

Oliveira, D.C., Magalhães, T.A., Ferreira, B.G., Teixeira, C.T., Formiga, A.T., Fernandes, G.W., and Isaias, R.M.S. 2014. Variation in the degree of pectin methylesterification 
during the development of Baccharis dracunculifolia kidney-shaped gall. PLoS ONE, 9(4): e94588. doi:10.1371/journal.pone.0094588.

Oliveira, D.C., Moreira, A.S.F.P., and Isaias, R.M.S. 2014. Functional Gradients in Insect Gall Tissues: Studies on Neotropical Host Plants. In Neotropical insect galls. Edited by G.W. Fernandes and J.C. Santos. Springer Netherlands, Dordrecht. pp. 35-49. Oliveira, D.C., Isaias, R.M.S., Moreira, A.S.F.P., Magalhães, T.A., and Lemos-Filho, J.P. 2011. Is the oxidative stress caused by Aspidosperma spp. galls capable of altering leaf photosynthesis? Plant Sci. (Limerick), 180: 489-495. doi:10.1016/j.plantsci.2010.11.005. Oliveira, D.C., and Isaias, R.M.S. 2010. Redifferentiation of leaflet tissues during midrib gall development in Copaifera langsdorffii (Fabaceae). S. Afr. J. Bot. 76: 239-248. doi:10.1016/j.sajb.2009.10.011.

Oliveira, D.C., Magalhães, T.A., Carneiro, R.G.S., Alvim, M.N., and Isaias, R.M.S. 2010. Do Cecidomyiidae galls of Aspidosperma spruceanum (Apocynaceae) fit the preestablished cytological and histochemical patterns? Protoplasma, 242: 81-93. doi:10.1007/s00709-010-0128-6.

Ridley, B.L., O’Neill, M.A., and Mohnen, D. 2001. Pectins: structure, biosynthesis, and oligogalacturonide-related signaling. Phytochemistry, 57: 929-967. doi:10.1016/S00319422(01)00113-3.

Rohfritsch, O. 1992. Patterns in gall development. In Biology of insect-induced galls. Edited by J.D. Shorthouse and O. Rohfritsch. Oxford University, Oxford. pp. 60-86.

Sabba, R.P., and Lulai, E.C. 2005. Immunocytological analysis of potato tuber periderm and changes in pectin and extension epitopes associated with periderm maturation. J. Am. 
Soc. Hortic. $\quad$ Sci. 130: 936-942. Available from http://journal.ashspublications.org/content/v 130/6/936.full.pdf. [accessed 23 June 2017]. Shorthouse, J.D., Wool, D., and Raman, A. 2005. Gall-inducing insects - Nature's most sophisticated herbivores. Basic Appl. Ecol. 6: 407-411. doi:10.1016/j.baae.2005.07.001. Showalter, A.M. 1993. Structure and function of plant cell wall proteins. Plant Cell, 5: 923. doi:10.1105/tpc.5.1.9.

Stone, G.N., and Schonrogge, K. 2003. The adaptive significance of insect gall morphology. Trends Ecol. Evol. 18: 512-522. doi:10.1016/S0169-5347(03)00247-7.

Smallwood, M., Yates, E.A., Willats, W.G.T., Martin, H., and Knox, J.P. 1996. Immunochemical comparison of membrane-associated and secreted arabinogalactanproteins in rice and carrot. Planta, 198: 452-459. doi:10.1007/BF00620063.

Smallwood, M., Martin, H., and Knox, J.P. 1995. An epitope of rice threonine and hydroxyproline-rich glycoprotein is common to cell wall and hydrophobic plasma membrane glycoproteins. Planta, 196: 510-522. doi:10.1007/BF00203651.

Suzuki, A.Y.M., Bedetti, C.S., and Isaias, R.M.S. 2015. Detection and distribution of cell growth regulators and cellulose microfibrils during the development of Lopesia sp. galls on Lonchocarpus cultratus (Fabaceae). Botany, 93: 435-444. doi:10.1139/cjb-2015-0012. Vanderbosch, K.A., Bradley, D.J., Knox, J.P., Perotto, S., Butcher, G.W., and Brewin, N.J. 1989. Common components of the infection thread matrix and the intercellular space identified by immunocytochemical analysis of pea nodules and uninfected roots. EMBO J. 8: 335-342. Available from https://www.ncbi.nlm.nih.gov/pmc/articles/PMC400811/. [accessed 25 June 2017]. 
Willats, W.G.T., Marcus, S.E., and Knox, J.P. 1998. Generation of a monoclonal antibody specific to $(1 \rightarrow 5)-\alpha-L-a r a b i n a n$. Carbohydr. Res. 308: 149-152. doi:10.1016/S00086215(98)00070-6.

Zhang, G.F., and Staehelin, L.A. 1992. Functional compartmentation of the Golgi apparatus of plant cells: immunocytochemical analysis of high-pressure frozen- and freezesubstituted sycamore maple suspension culture cells. Plant Physiol. 99: 1070-1083. doi:10.1104/pp.99.3.1070.

\section{Captions}

Figure 1. Leaf anatomy of Croton floribundus. (A) Epidermis on the adaxial surface. (B) Epidermis on the abaxial surface. (C) Cross section of the intercostal region. AT- Acicular trichome; CS-Columnar sclereid; DR- Druse; EAB- Epidermis on the abaxial surface; EAD- Epidermis on the adaxial surface; GT- Glandular trichome; LST- Lepidote-stellate trichome; ST- Stomata; VB- Vascular bundle.

Figure 2. External and anatomical structure of Clinodiplosis galls. (A) Macroscopic view of globoid gall (left) and larval chamber (right). (B) Start of insect induction on abaxial surface of leaf. (C) Young gall with homogeneous cortex. (D) Mature gall with three tissue zones. (E) Cortex of mature gall. (F) Cortex of senescent gall. AT- Acicular trichome; CXCortex; DR- Druse; EAB- Epidermis on the abaxial surface; EAD- Epidermis on the adaxial surface; GG- Globoid gall; IC- Inner cortex; IN- Inductor; L- Leaf; LC- Larval chamber; MC- Median cortex; OC- Outer cortex; VB- Vascular bundle. 
Figure 3. Distribution and intensity of pectins and proteins in the cell wall in tissues of the leaf and Clinodiplosis galls. (A) Leaf. (B) Young gall. (C) Mature gall. (D) Senescent gall. EAD- Epidermis on the adaxial surface; EAB- Epidermis on the abaxial surface; ATAcicular trichome; CX- Cortex; EP- Epidermis; IC- Inner cortex; LC- Larval chamber; LST- Lepidote-stellate trichome; MC- Median cortex; OC- Outer cortex; PP- Palisade parenchyma; SP- Spongy parenchyma. (see Table 1 for full names of monoclonal antibodies).

Figure 4. Immunocytochemistry for LM1, LM2, LM5 and LM6 antibodies in different stages of development of Clinodiplosis galls. (A) LM1 labeled the epitopes of extensins in the epidermis, trichomes and in the outer cortex of senescent galls. (B) LM2 labeled the epitopes of AGP-glycans in the outer cortex of senescent galls. (C, D) LM5 labeled the epitopes of $\beta$-D-galactans in the cortex, trichomes and vascular bundle in young galls. (E) LM5 labeled the epitopes of $\beta$-D-galactans in trichomes and in the outer cortex in senescent galls. (F) LM6 labeled the epitopes of $\alpha$-L-arabinans in the epidermis, trichomes and cortex of young galls. AT- Acicular trichome; CX- Cortex; EP- Epidermis; LC- Larval chamber; MC- Median cortex; OC- Outer cortex; OS- Ostiole; PH- Phloem.

Figure 5. Immunocytochemistry for LM6, JIM5 and JIM7 antibodies in the tissues in different stages of development of Clinodiplosis galls. (A) LM6 labeled the epitopes of $\alpha-$ L-arabinans in the trichomes, outer, median and inner cortex of mature gall. (B) JIM5 labeled the epitopes of low methylesterification pectins in the trichomes of young galls. (C) 
JIM5 labeled the epitopes of low methylesterification pectins in the outer and median cortex of mature gall. (D-F) JIM7 labeled the epitopes of high methylesterification pectins in all tissues of young gall (D,E) and mature gall (F). AT- Acicular trichome; CX- Cortex; EP- Epidermis; IC- Inner cortex; IN- Inductor; LC- Larval chamber; MC- Median cortex; OC- Outer cortex; OS- Ostiole. 
Table 1. Monoclonal antibodies and their epitopes used for labeling proteins and pectins in the leaf and in globoid Clinodiplosis galls.

\begin{tabular}{lll}
\hline Monoclonal antibodies & Epitopes & Authors \\
\hline & Proteins & Smallwood et al. (1995); Leroux et al. (2011). \\
LM1 & Extensins & Yates et al. (1996); Smallwood et al. (1996). \\
LM2 & AGP glycan & \\
& Pectin compounds & Jones et al. (1997). \\
LM5 & $(1 \rightarrow 4) \beta$-D- galactan & Willats et al. (1998). \\
LM6 & $(1 \rightarrow 5) \alpha-L-$ arabinans & Vanderbosch et al. (1989); Clausen et al. (2004). \\
JIM5 & HGA partially methyl-esterified up to 40\% & \\
JIM7 & HGA (15-80\% methyl-esterified) & Knox et al. (1990); Clausen et al. (2004). \\
\hline
\end{tabular}




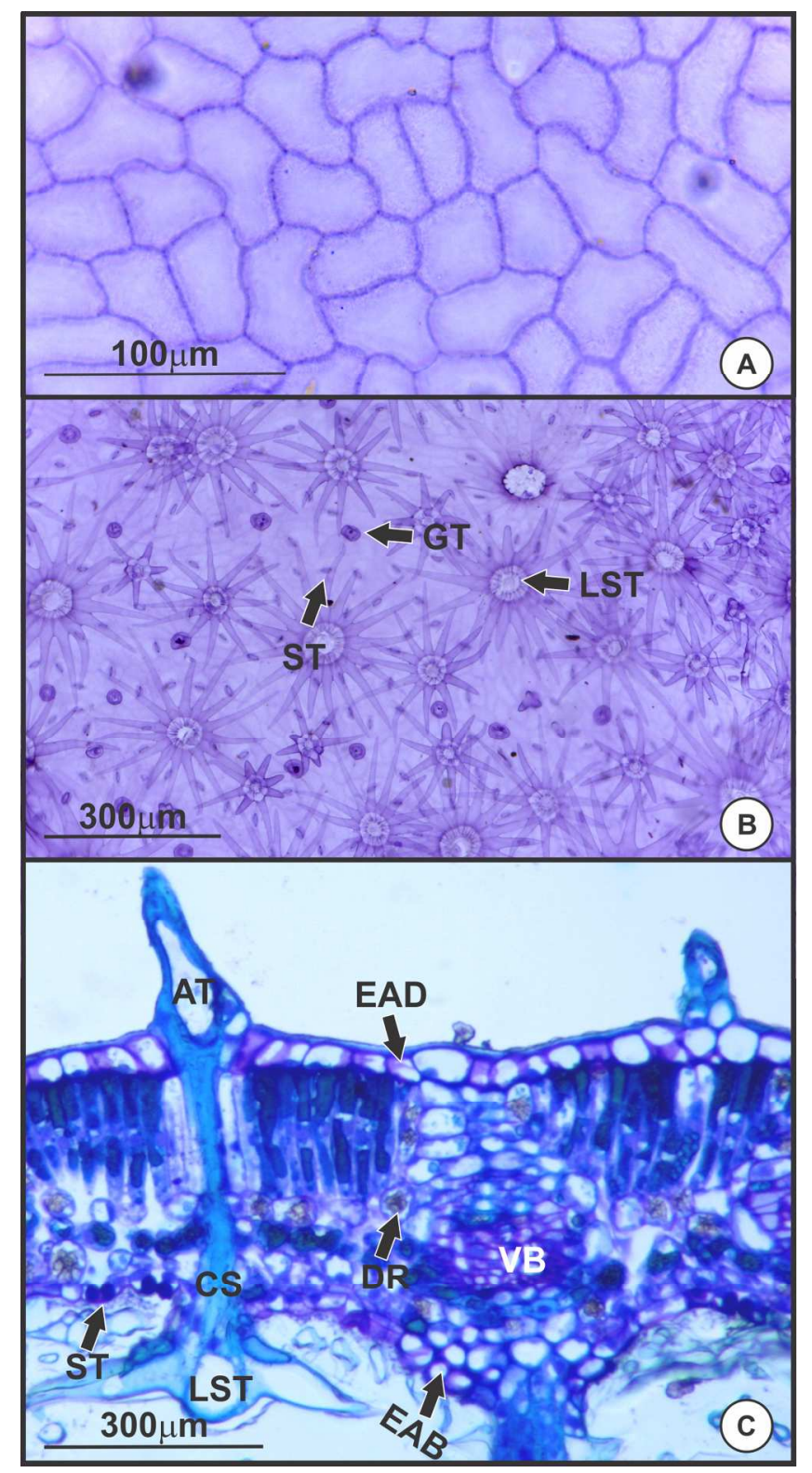

Figure 1. Leaf anatomy of Croton floribundus. A- Epidermis on the adaxial surface; B- Epidermis on the abaxial surface; C-Cross section of the intercostal region. AT- Acicular trichome; CS- Columnar sclereid; DR- Druse; EAB- Epidermis on the abaxial surface; EAD- Epidermis on the adaxial surface; GT- Glandular trichome; LST- Lepidote-stellate trichome; ST- Stomata; VB- Vascular bundle.

$110 \times 207 \mathrm{~mm}(300 \times 300 \mathrm{DPI})$ 


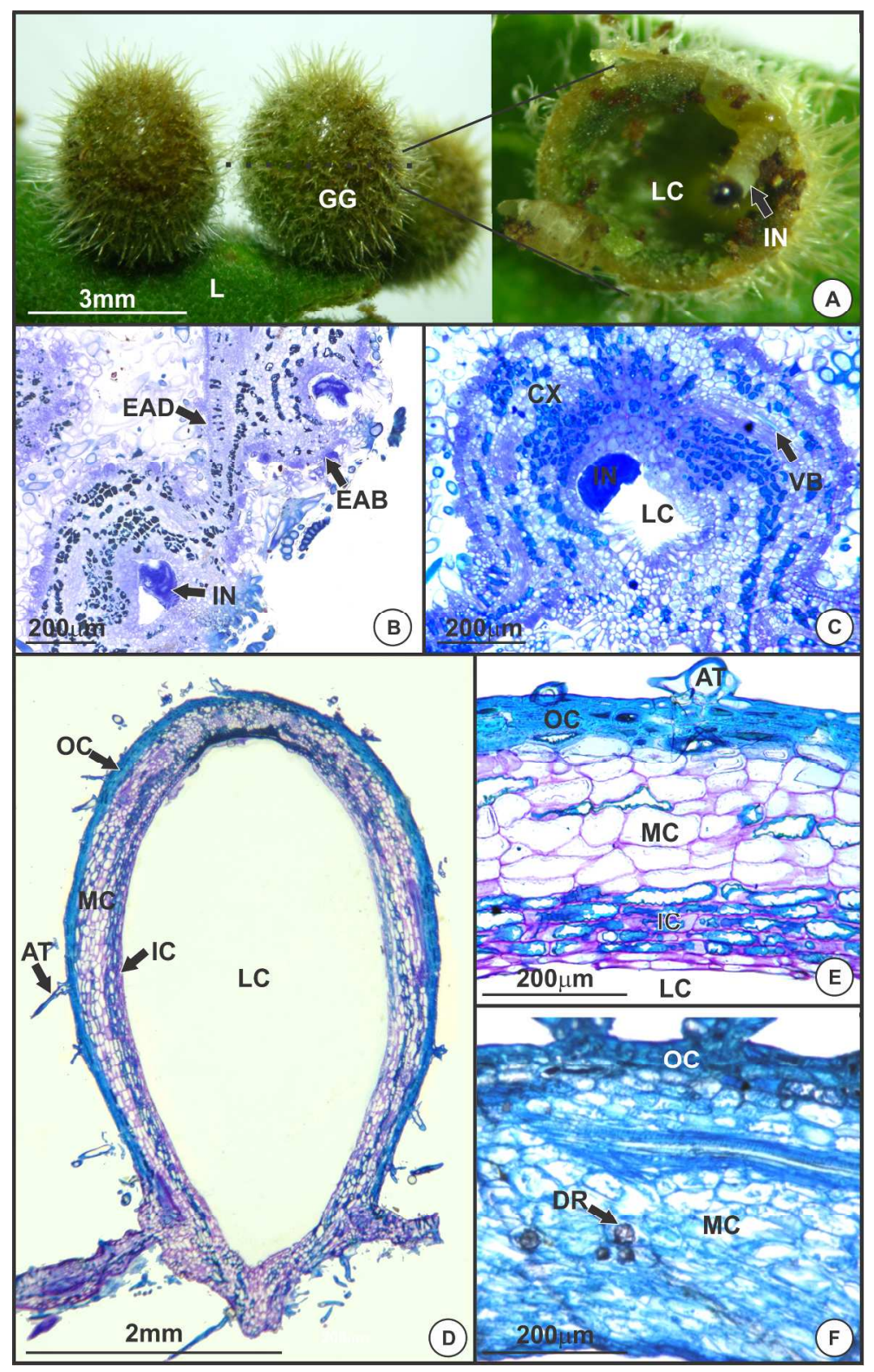

Figure 2. External and anatomical structure of Clinodiplosis galls. A- Macroscopic view of globoid (left) galls and larval chamber (right); B- Start of insect induction on abaxial surface of leaf; C- Young gall with homogeneous cortex; D- Mature gall with three tissue zonation; E- Cortex of mature gall; F- Cortex of senescent gall. AT- Acicular trichome; CX-Cortex; DR- Druse; EAB- Epidermis on the abaxial surface; EADEpidermis on the adaxial surface; GG- Globoid gall; IC- Inner cortex; IN- Inductor; L- Leaf; LC- Larval chamber; MC- Median cortex; OC- Outer cortex; VB- Vascular bundle. 


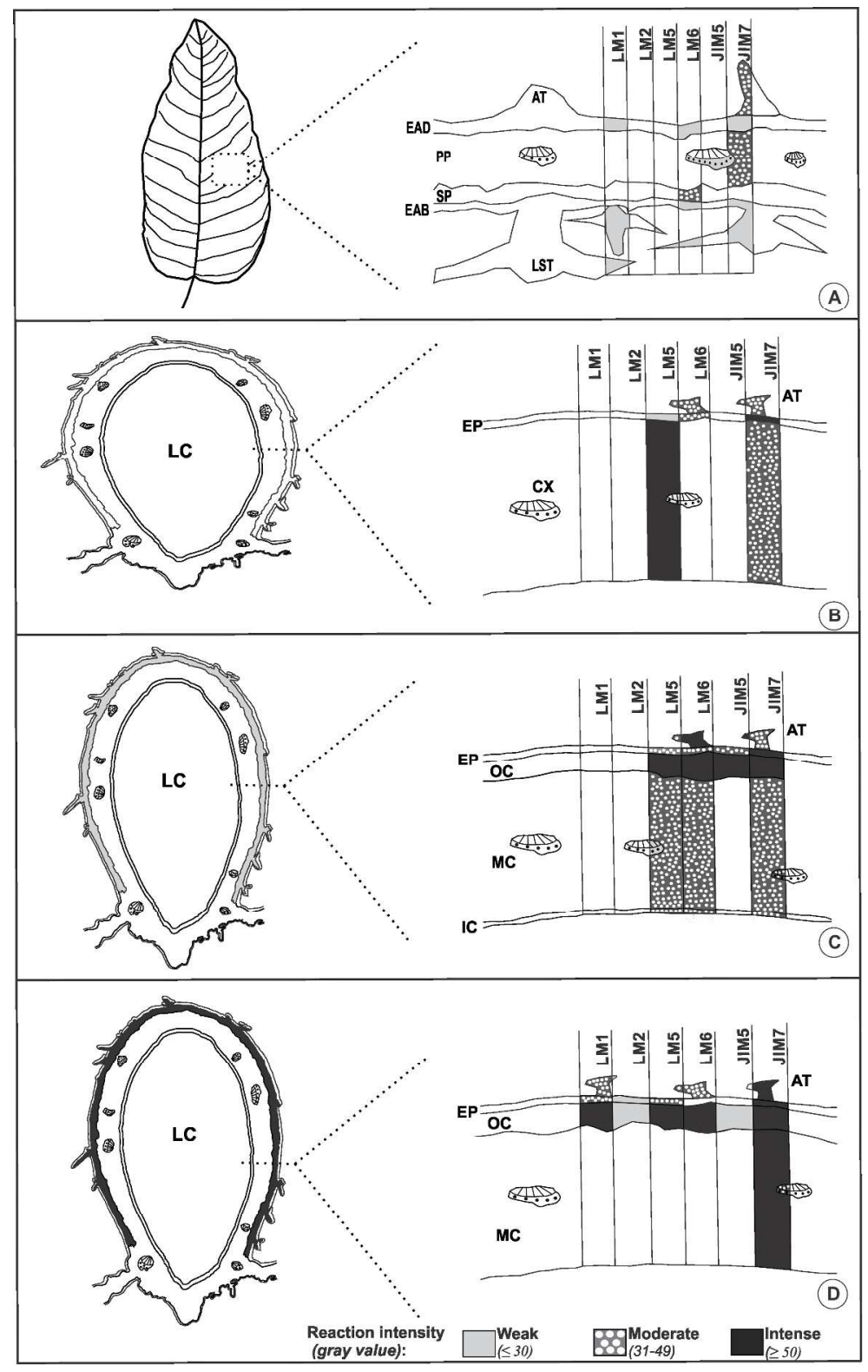

Figure 3. Distribution and intensity of pectins and proteins in cell wall in tissues of the leaf and Clinodiplosis galls. A- Leaf; B- Young gall; C- Mature gall; D- Senescent gall. EAD- Epidermis on the adaxial surface; EABEpidermis on the abaxial surface; AT- Acicular trichome; CX-Cortex; EP- Epidermis; IC- Inner cortex; LCLarval chamber; LST- Lepidote-stellate trichome; MC- Median cortex; OC- Outer cortex; PP- Palisade parenchyma; SP- Spongy parenchyma. (see Table 1 for full names of monoclonal antibodies).

$$
225 \times 360 \mathrm{~mm}(300 \times 300 \mathrm{DPI})
$$




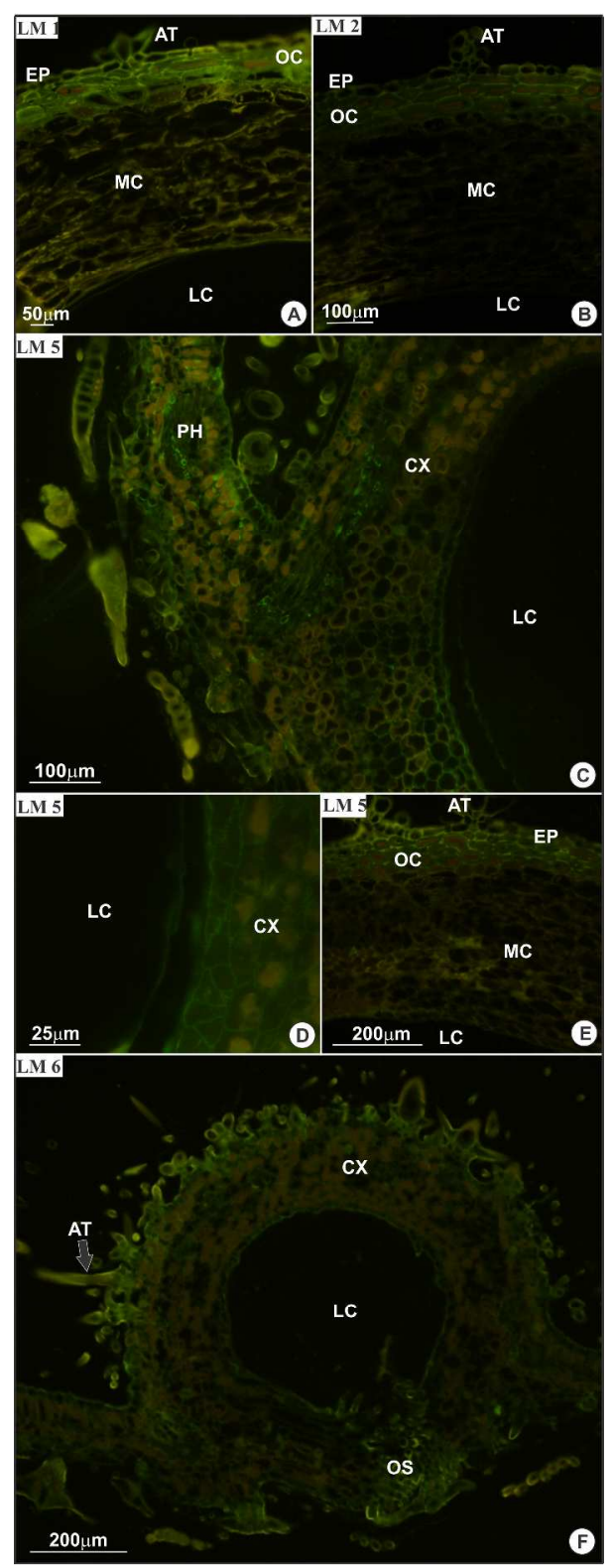

Figure 4. Immunocytochemistry for LM1, LM2, LM5 and LM6 antibodies in different stages of development of Clinodiplosis galls. A- LM1 labeled the epitopes of extensins in the epidermis, trichomes and in the outer cortex of senescent galls; B- LM2 labeled the epitopes of AGP-glycans in the outer cortex of senescent galls; C, D- LM5 labeled the epitopes of $\beta$-D-galactans in the cortex, trichomes and vascular bundle in young galls; E- LM5 labeled the epitopes of $\beta$-D-galactans in trichomes and in the outer cortex in senescent galls; F- LM6 labeled the epitopes of a-L-arabinans in the epidermis, trichomes and cortex of young galls. AT- Acicular trichome; CX- Cortex; EP- Epidermis; LC- Larval chamber; MC- Median cortex; OC- Outer cortex; OSOstiole; PH- Phloem. 


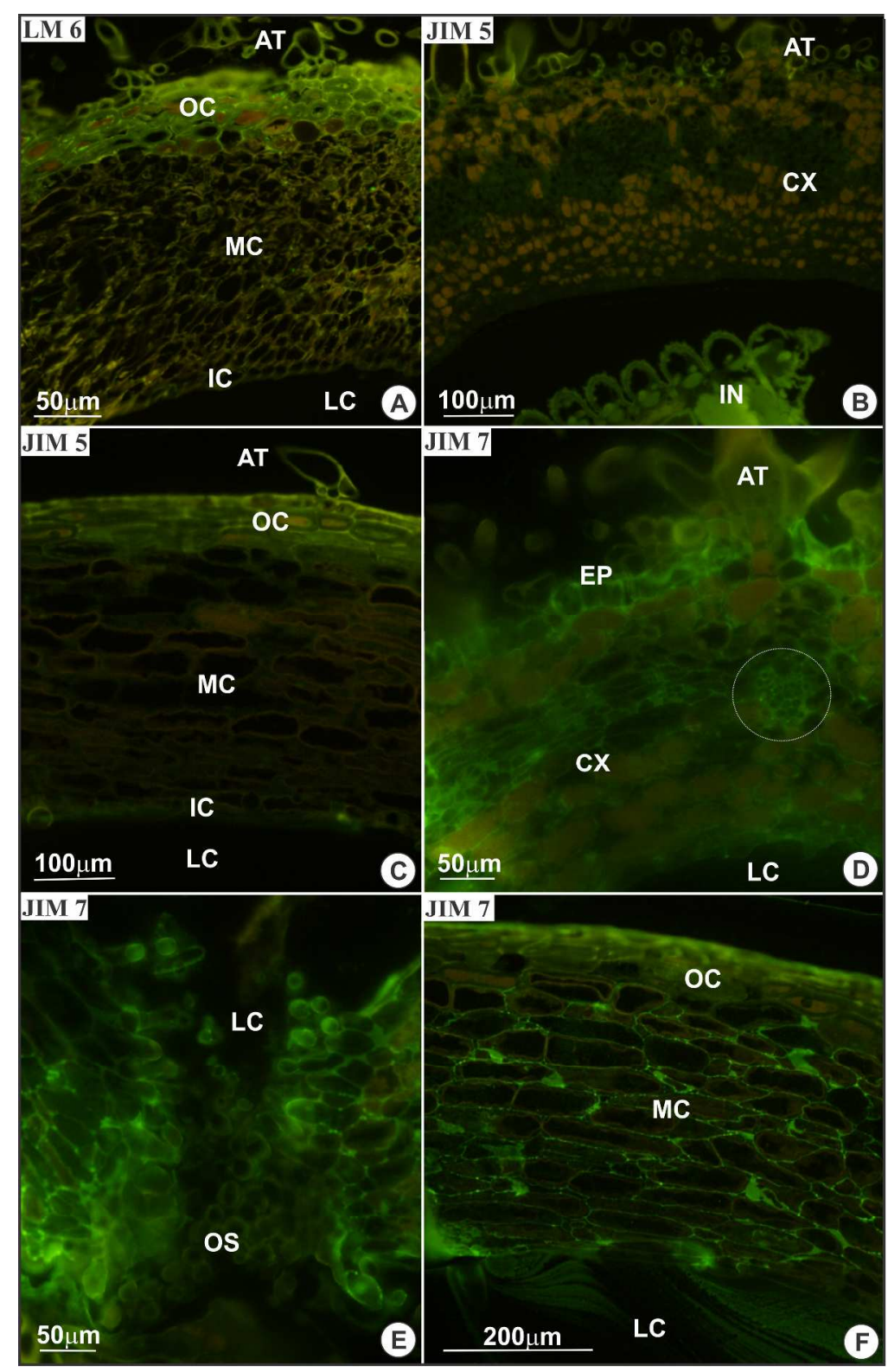

Figure 5. Immunocytochemistry for LM6, JIM5 and JIM7 antibodies in the tissues in different stages of development of Clinodiplosis galls. A- LM6 labeled the epitopes of a-L-arabinans in the trichomes, outer, median and inner cortex of mature gall; B- JIM5 labeled the epitopes of low methylesterification pectins in the trichomes of young galls; C- JIM5 labeled the epitopes of low methylesterification pectins in the outer and median cortex of mature gall; D-F- JIM7 labeled the epitopes of high methylesterification pectins in all tissues of young gall $(D, E)$ and mature gall $(F)$. AT- Acicular trichome; CX- Cortex; EP- Epidermis; IC- Inner cortex; IN- Inductor; LC- Larval chamber; MC- Median cortex; OC- Outer cortex; OS- Ostiole.

$$
244 \times 380 \mathrm{~mm}(300 \times 300 \text { DPI) }
$$

